\title{
Em cartaz: o cinema brasileiro de autor na cartografia cultural mundial
}

Maria Angélica Amâncio

\section{Introdução}

"O que não está em nenhum lugar não existe." Aristóteles, Física

O cinematógrafo e, com ele, a arte cinematográfica, desembarcaram no Brasil, pelas mãos de Afonso Segreto, em 1898, apenas três anos após seu surgimento na França. Contudo, o cinema jamais alcançou aqui a popularidade e a adoração de que goza em diversos países europeus, nos Estados Unidos ou em vizinhos como a Argentina. Ainda que dados recentes da Ancine comemorem recordes de lançamento, público e renda ${ }^{1}$, sabe-se que ocorre simplesmente uma permuta de elites no meio cinematográfico, trocando-se o capital estrangeiro, de Hollywood, pelo grande capital nacional, da Globo Filmes. ${ }^{2} \mathrm{O}$ público brasileiro, de maneira geral, conhece pouco a vertente mais original dessa produção, limitando-se a ver, reproduzido na grande tela e condensado em duas horas de duração, um simulacro das novelas ou programas de humor a que ele já assiste na TV.

Por outro lado, é curioso constatar que, no exterior, um número cada vez maior de pessoas vem descobrindo as qualidades de nosso cinema. Uma forma de medir esse interesse é o surgimento de publicações acadêmicas, escritas por pesquisadores estrangeiros, a esse respeito. É o caso de The Brazilian Road Movie: Journeys of (Self) Discovery. (2013), de Sara Brandellero, Professora de Leiden University, na Holanda; e Cinéma et littérature au Brésil - Les mythes du Sertão: émergence d'une identité nationale (2003), de Sylvie Debs, Professora da Université Robert Schuman Strasbourg, na França.

Essa expansão pode ser medida também pela quantidade crescente de festivais dedicados à produção cinematográfica brasileira, ao redor do mundo. Los Angeles acaba de assistir, em novembro deste ano de 2017, à décima edição do Los Angeles Film Festival, enquanto o Festival du Film Brésilien de Montréal aconteceu pela décima primeira vez, em outubro, e o Brazilian Film Festival, de Miami, pela vigésima primeira vez, em setembro³. Na França - que homenageou a literatura brasileira no Salão do Livro de 2015 -, o Festival du

\footnotetext{
${ }^{1}$ Disponível em: <https://www.ancine.gov.br/pt-br/sala-imprensa/noticias/bilheteria-cresce-e-filmes-brasileiros-batemrecorde-de-lan-amentos-em-2016> Acesso: 22 nov. 2017.

${ }^{2}$ Disponível em: < http://www.cartamaior.com.br/?/Editoria/Cultura/O-cinema-brasileiro-vai-bem-/39/31077> Acesso: 22 nov. 17.

${ }^{3}$ Para mais informações sobre festivais de cinema brasileiro, consultar: <http://www.inffinito.com/>. Acesso: 13 jul. 15.
} 
Cinéma Brésilien de Paris teve, em junho de 2017, sua décima nona edição. Uma parte da programação deste evento é, inclusive, dedicada às adaptações literárias, e exibe filmes como Dona Flor e seus dois maridos (1976), de Bruno Barreto, e Capitães de areia (2011), de Cecília Amado - ambos adaptados de romances de Jorge Amado -, colaborando, portanto, na difusão de forma de produção cultural brasileira.

Contudo, a frequência desses festivais não é suficientemente regular em todos os lugares. Na cidade de Buenos Aires, por exemplo, o evento deixou de acontecer por três anos - entre 2011 e 2013 -, e, em Roma e Barcelona, ele não se repete desde 2009. Esses dados alertam para o fato de que o reconhecimento depende, muitas vezes, da persistência. Investir somente esporadicamente em exibições que divulguem o cinema nacional não tornará possível uma valorização permanente. E fato é que a produção audiovisual brasileira sofre ainda com a irregularidade da distribuição: apenas em 2006, foi fundada a agência Cinema do Brasil, no intuito de ampliar a participação de nosso cinema no mercado internacional. Mesmo assim, observa-se ainda uma grande dependência das grandes distribuidoras estrangeiras.

Outra dificuldade com a qual nossa cinematografia convive, há muitas décadas, se associa à abordagem constante que realiza de certos temas. Deixando para trás o estereótipo da pornochanchada, da década de 1970, o cinema nacional adotou outros rótulos, como o da miséria e o da violência, em filmes como Pixote, a lei do mais fraco (1980), de Hector Babenco, Cidade de Deus (2002), de Fernando Meirelles e Kátia Lund, e Tropa de Elite (2007), de José Padilha.

Também o regionalismo, quando intensamente explorado, dificulta a empatia do público estrangeiro com os personagens e as tramas brasileiras. É o caso de filmes como "Ó Paí ó" (2007), de Monique Gardenberg, que aborda, de modo demasiadamente folclórico, as peculiaridades nacionais ou de uma determinada região, o nordeste.

É evidente que nem a temática nem o regionalismo são, por si só, problemáticos. Pelo contrário: é importante desvelar a grandeza de um país que é muito mais do que o eixo RioSão Paulo, disseminando a riqueza das diferentes culturas em convívio nessa nação de dimensões continentais. É, ao mesmo tempo, fundamental perceber o cinema como um instrumento de denúncia da realidade, capaz de sensibilizar para a crueldade da vida no sertão, nas favelas, nos presídios e reformatórios. Contudo, é necessário também transpor esse pragmatismo, apresentando, para brasileiros e estrangeiros, outros temas e outras formas de se fazer cinema no Brasil.

Antes de tudo, porém, é preciso entender o cinema brasileiro como aquilo que é em essência, ou seja, cinema. Por várias décadas, essa mídia não foi considerada uma arte em si, devendo ser comparada a outras, como a literatura e a fotografia, para encontrar 
legitimidade. Aos poucos, porém, o cinema se fortalece como linguagem, dados seu ritmo próprio, sua evolução estilística, seus meios particulares de articulação de cenas, sequências, estruturas narrativas. Abordagens teóricas como as de Marcel Martin (2003) e de Christian Metz (1971) merecem destaque, nesse sentido, pelo fato de considerarem que a linguagem cinematográfica surge à medida que os procedimentos fílmicos e as escolhas estilísticas se desenvolvem - daí a importância de cineastas como D.W. Griffith e S.M. Eisenstein. Martin preferiria, inclusive, o termo estilo a linguagem.

Por essa razão é que, neste trabalho, pretende-se analisar o cinema brasileiro contemporâneo pela vertente dos cineastas, aqueles que acredita-se serem capazes de transgredir diferentes fronteiras: temporais, espaciais, formais. Desse modo, observa-se de que maneira autores como Walter Salles ${ }^{4}$, Felipe Barbosa e Kleber Mendonça Filho, cada um à sua maneira, contribuem para inscrever o cinema brasileiro, autêntico e renovado, na cartografia mundial.

\section{I}

O primeiro longa-metragem de ficção do roteirista e diretor Kleber Mendonça Filho, O som ao redor (2012), problematiza o espaço, explorando elementos sonoros e evocando questões históricas e sociais. Os ruídos, de fato, se fazem ouvir desde o princípio: uma percussão marcial, as rodas de patins deslizando no interior de uma garagem repleta de automóveis modernos, crianças brincando no playground, um serralheiro que coloca uma grade de proteção em uma janela. Porém, O som ao redor é, sobretudo, um filme sobre a segregação.

É isso o que se insinua já nas cenas mencionadas: o espectador tem acesso, por uma câmera instável, que acompanha o movimento dos personagens, ao subsolo desse condomínio de classe média alta. No espaço de lazer, onde as crianças, todas brancas, andam de bicicleta, brincam com bambolês, jogam futebol, há um local reservado às babás: o escanteio. Com uniformes de cores pálidas, largos, que apagam explicitamente qualquer traço de sensualidade, de feminilidade, elas são quase tão numerosas quanto as crianças em cena, mas dela só participam como coadjuvantes.

Esta é a primeira de muitas tomadas em que a diferença de classes e etnias é abordada na trama, que se desenrola quase inteiramente na cidade de Recife. O título, aliás, foi traduzido, na França, como Les bruits de Recife -, escolha que, como demonstraremos adiante, desconsidera importantes cenas gravadas no município de Bonito-PE. A maior

\footnotetext{
${ }^{4}$ Embora o filme de Walter Salles escolhido para análise seja também dirigido por Daniela Thomas, focaliza-se o cineasta, por razões que serão compreendidas na Conclusão.
}

$3^{\text {RASILIANA- Journal for Brazilian Studies. Vol. 6, n.1 (December, 2017). ISSN 2245-4373. }}$ 
parte da ação, porém, acontece na Rua Setúbal, localizada no bairro homônimo. É a rua o protagonista desse enredo: por ela, os carros circulam e se chocam; sobre seu asfalto, se escrevem mensagens de amor, votos de feliz aniversário, a serem lidos da janela dos prédios, que, numerosos, verticalizam o olhar dos passantes. Além da rua, outros personagens se destacam, nessa multiplicidade de histórias emaranhadas.

Em primeiro lugar, o espectador conhece Bia (Maeve Jinkings), mãe de família, jovem dona de casa que, às vezes entediada, distrai-se oferecendo, aos eletrodomésticos, usos pouco habituais: a máquina de lavar, por exemplo, é instrumento de masturbação, enquanto o aspirador de pó suga a fumaça expelida do cigarro de maconha. Em seguida, apresentase João (Gustavo Jahn), o bom-moço, que é cordial com as empregadas, defende os direitos do porteiro do prédio junto aos demais condôminos, busca justiça quando o aparelho de CD é roubado do carro da namorada, Sofia (Irma Brown), pelo primo Dinho (Yuri Holanda). Este representa o marginal de classe média, que realiza, por diversão, determinados delitos, certo da impunidade gerada, sobretudo, pela importância do avô, que o protege: Francisco Oliveira (Waldemar José Solha), antigo senhor de engenho, é o proprietário de mais da metade dos imóveis da rua Setúbal e principal autoridade no local.

É a ele que se deve pedir "bênção" quando se pretende iniciar um novo negócio na região, como o serviço de segurança oferecido por Clodoaldo Pereira dos Santos (Irandhir Santos) e sua equipe. O monitoramento da rua, a princípio, desperta a desconfiança de alguns moradores, que julgam tratar-se de uma espécie velada de coerção. No entanto, diante do aumento no número crimes, e da falibilidade dos cães de guarda e sistemas de segurança, os cidadãos acabam concordando em pagar pelo serviço, cuja importância para a história não pode passar despercebida. Ela se faz imediatamente notar pelas rubricas que denominam a divisão da trama em três capítulos: “Cães de guarda”, "Guardas noturnos" e "Guarda-costas". Segundo Ivone Daré Rabello,

os títulos, com as diferenças de agentes (cães, homens e capangas), assinalam não apenas um mesmo fenômeno, mas sobretudo sua intensificação: a necessidade de defender a propriedade privada é diretamente proporcional à ameaça (fantasmática ou não) que paira sobre as coisas e os corpos (RABELLO, 2015, p.157).

A propriedade privada está no centro dessa obra, sendo salientada a todo o momento. Os interiores são filmados demoradamente, como se a câmera fosse o proprietário que apresenta, ao espectador, a casa que se visita pela primeira vez. Mesmo o ofício de um dos personagens do núcleo principal favorece essa perambulação: como corretor de imóveis, 
João exibe, a possíveis compradores ou inquilinos, os apartamentos do avô, utilizando o jargão imobiliário: "duas vagas na garagem", "180m²”, "quatro suítes”, e, claro, "segurança 24 horas".

Como em qualquer centro urbano, também em Recife, na rua Setúbal, a grande preocupação dos moradores é com a segurança - “a primeira das liberdades”, como declaram, em seus discursos, diversos homens políticos franceses ${ }^{5}$. Os condôminos do prédio de João se revoltam e querem demitir, "por justa causa", apesar das décadas de bons serviços prestados, o porteiro que, idoso e cansado, agora dorme no serviço, colocando hipoteticamente em risco a segurança dos habitantes. Até as crianças, com a filha menor de Bia, têm pesadelos, nos quais uma miríada de assaltantes invade a propriedade familiar. Contudo, as cercas elétricas, os vigias e os cães raivosos só fazem escancarar algumas verdades relativas àquele espaço.

A primeira delas diz respeito ao sentido expandido de propriedade. Em determinado momento, Clodoaldo ameaça Dinho por telefone, desrespeitando, assim, as ordens do Sr. Francisco, que exigira que seu neto não fosse incomodado por ele e sua equipe, independente dos crimes que cometesse. O jovem, então, vai até a guarida dos seguranças e retribui a intimidação, dizendo: "Essa rua é de minha família. Gente grande, de dinheiro. Essa rua não é favela". A afirmação por oposição, em que se engrandece a rua, "de sua família”, por aquilo que ela não é, “a favela", estabelece um intervalo, um abismo, também entre o que ele, Dinho - herdeiro, branco, rico - é, em relação ao que ele não é, e ao que aqueles homens diante dele são: trabalhadores, mulatos, pobres.

Esse limite é visivelmente percebido por outros personagens, como os guardadores de carros, que dizem não saber de nada sobre as ações de Dinho, mesmo quando seu primo, João - portanto, tão neto de Francisco quanto o primeiro -, pede informações sobre o roubo já mencionado. Outra cena emblemática para se medir o poder da família Oliveira e, especialmente, a impavidez do velho senhor de engenho, é aquela em que, à noite, este deixa seu apartamento e vai caminhando tranquilamente até a beira da praia. Ali ele tira os chinelos, a camiseta, e mergulha no mar revolto, apesar da placa em que se lê: "Perigo: área sujeita a ataque de tubarão".

Francisco enfrenta os perigos da noite; despreza a vulnerabilidade que pode ser inspirada por um homem de sua idade, desacompanhado, na mente de bandidos; desafia o mar e até mesmo os tubarões. Afinal, quem ousaria atacá-lo? Ao mesmo tempo, porém, a cena pode ser vista por outro ângulo: a placa de "Perigo" seria um alerta para o próprio

\footnotetext{
5 A máxima "La sécurité est la première des libertés" ou "La première liberté, c'est la sécurité" foi utilizada por políticos como o primeiro-ministro Pierre Mauroy, em 1981, Nicolas Sarkozy, em 2002, e Manuel Valls, em 2015. Cf.: $<\underline{\text { http://www.telerama.fr/medias/la-securite-est-la-premiere-des-libertes-de-le-pen-a-valls-la-formule-s-est-imposee- }}$ dans-le-debat-politique, 134465.php> Consulta em: 24 nov. 2017.
} 
espectador, convidado a considerar Francisco como o tubarão a ser temido. É ele o predador que manda e desmanda naquele local, o indivíduo abastado cuja fonte de riqueza, da qual Dinho se vangloria, é a exploração do trabalho escravo. É justamente por isso que a casa de engenho, lugar de predileção do patriarca, situa-se na região de Bonito, que, como destaca Rabello,

Atualmente, [...] é uma região turística em que se vende a beleza das cachoeiras. No entanto, ali se travaram lutas e massacres de escravos e de camponeses: no século XVII, estabeleceu-se o Quilombo dos Palmares; ao final de 1819, na serra do Rodeador, ocorreu revolta messiânica contra a miséria, liderada por Silvestre José dos Santos; em dezembro de 1874, a Revolta dos Quebra-Quilos (RABELLO, 2015, p.167).

Conforme observado pela pesquisadora, quando João e Sofia visitam o avô na antiga casagrande, há duas sequências especialmente representativas. Na primeira, o casal passeia por um cinema abandonado, dominado pelo matagal e pela ferrugem. Ouvem-se ecos do que seriam filmes de terror, aos quais se teria assistido ali, em outra época, gritos de medo e de sofrimento. Na segunda, os três estão tomando banho de cachoeira, destemidos sob o peso violento da água que lhes cai sobre as costas. De repente, porém, a água se transforma em sangue - e o espectador vê João despertando do que teria sido um pesadelo. Todavia, tanto os gritos quanto o sangue podem ser interpretados como reverberações do passado doloroso vivido ali por uma multiplicidade de escravos.

A pertinência dessa interpretação é confirmada por outros elementos da trama, que conduzem à segunda verdade apresentada pelo filme: a da permanência da divisão de classes com base também na cor da pele. Como mencionado no início desta análise, as empregadas são numerosas no espaço retratado pela obra. E todas elas são negras ou mulatas, quase sempre servis e silenciosas diante dos patrões, brancos e autoritários. A única exceção se dá pela relação cordial de João com a empregada, Mariá. Na família há muitos anos, ela tem a liberdade de trazer as netas para o trabalho, quando necessário, e tem seus direitos respeitados, podendo, inclusive, se aposentar adequadamente. De resto, as domésticas são tratadas com indiferença e/ou maltratadas, como na cena em que a criada de Bia queima um utensílio importado, ao inseri-lo numa tomada de outra voltagem, e é veementemente insultada pela patroa.

Há, porém, momentos de desforra, em que o rancor acumulado vem à tona. Um deles advém da governanta de Francisco, Luciene (Clébia Sousa). A sequência começa com um enquadramento que coloca em paralelo o dono da casa - confortavelmente sentado, com os 
pés estendidos, lendo o jornal, ao lado da porta que dá para a sacada - e, no cômodo contíguo, Luciene, que recebe uma mensagem no celular. $\mathrm{O}$ espectador aproveita para espiar a decoração, o barzinho repleto de bebidas caras, os espelhos, as plantas, uma televisão de muitas polegadas, a escada onde outra doméstica, ajoelhada, trabalha. Luciene diz ao patrão que precisa ir até a lavanderia. Em seguida, atravessa a cozinha, ampla, inteiramente branca, sobe as escadas até seu quarto, já se despindo pelos degraus. A câmera interrompe seu movimento na entrada do cômodo minúsculo, de onde se vê um pequeno televisor, antigo, e a jovem que se prepara para sair, trocando o uniforme frouxo, de cores desbotadas, por uma saia curta e uma blusa tomara-que-caia. Não se vê o espelho, mas se percebe que ela está diante dele, soltando o coque que prendia os cabelos e penteando-se com mais vaidade. $\mathrm{O}$ espectador já desconfia que seu destino não seja, de fato, a lavanderia: Luciene vai encontrar Clodoaldo, seu amante. Ele a leva à casa de um vizinho que, viajando, o encarregara de aguar as plantas, deixando-lhe as chaves da residência.

O primeiro pequeno revide acontece quando ela pede água. Clodoaldo abre a geladeira, tira a jarra de vidro e lhe diz para beber diretamente dali. Depois, na sala, ela se incomoda com a brancura da decoração: as paredes, os móveis, a porcelana. Eles sobem as escadas - a pedido dela, que quer conhecer o quarto dos patrões -, e se encontram novamente em um cômodo inteiramente branco, incluindo a colcha que cobre a cama dos proprietários, sobre a qual os empregados têm suas relações sexuais. Enquanto isso acontece, o telefone toca, insistente, e o espectador leva um susto, ao ver passar, correndo pelo corredor, um menino negro, vestido apenas com uma bermuda larga, bege, semelhante às vestimentas dos escravos nas representações pictóricas.

A aparição não é esclarecida, na obra, assim como não se explica o surgimento de outro menino, vestido da mesma maneira, no alto de uma árvore. Encontrado pelos colegas de Clodoaldo, ele é agredido e enxotado, para que não volte mais àquela vizinhança. Há, portanto, uma diferenciação, mesmo entre aqueles que poderiam ser considerados iguais. Essa cisão inviabiliza a organização de classe, e os mais pobres continuam se submetendo às vontades dos patrões. A revanche acaba por se restringir a atos individuais, menos ou mais violentos, que, no entanto, não desestabilizam a lógica de exploração capitalista, racista, que se observa na rua Setúbal, simulacro do Brasil contemporâneo.

Ao mesmo tempo, porém, há algo de muito poderoso nesse rancor que inspira o enfrentamento de classes, a revanche, a invasão. A terceira verdade apreendida no filme é a da ameaça que transcende as cercas elétricas, que sobe os muros e adentra as propriedades privadas, como fantasmas correndo seminus pelos corredores. Por mais que a classe média se feche na ilusão de seus sistemas de segurança, ela nunca está, de fato, segura - nem no sentido de certeza, nem no de proteção. Por isso, acumula meios de se proteger, que podem 
vir a ser suas próprias armadilhas. Nesse sentido, o som, em destaque no filme já pelo título, apresenta um significado interessante: como os fantasmas e os pesadelos, o som invade também o espaço, ignorando os muros das fortalezas.

Um dos embates mais contundentes da obra é o de Bia com o cão de guarda da residência vizinha. A dona-de-casa perde o sono por causa dos latidos do animal e, por essa razão, tenta drogá-lo, assustá-lo, silenciá-lo de todas as maneiras. Os uivos do cão, porém, persistem, desrespeitando as grades enferrujadas pelas quais a mulher o observa. O som é o inferno sartriano, que atesta a existência dos outros, inevitável, apesar das cercas elétricas, dos condomínios fechados, dos guarda-costas. O som debocha do espaço, ao atravessá-lo.

\section{II}

Na estrada. Diários de Motocicleta. Central do Brasil. Terra Estrangeira. Os títulos das principais obras do diretor carioca, Walter Salles, evocam, por si só, questões relativas ao movimento, ao espaço, à partida, à busca. Embora nem todos possam ser considerados road movies propriamente ditos, Salles domina, sem dúvida, a arte de combinar, a elementos psicológicos, políticos, socioculturais, o deslocamento físico de seus personagens, por espaços mais ou menos restritos.

Dirigido em parceria com Daniela Thomas, seu primeiro longa-metragem de destaque, Terra Estrangeira (Brasil/Portugal - 1995) é lançado em um período que, ainda que controversamente, ficou conhecido como Retomada do Cinema Brasileiro ${ }^{6}$. Após a posse do presidente Fernando Collor de Melo, no início da década de 1990, o país assistiu à paralisação de várias políticas culturais, a transformação do Ministério da Cultura em Secretaria, a extinção da Embrafilme (Empresa Brasileira de Filmes S.A.), do Concine e da Fundação de Cinema Brasileiro - o que gerou praticamente a anulação da produção cinematográfica nacional. Contudo, com o impeachment do presidente, em 1992, e a partir da promulgação da Lei do Audiovisual e de outras leis de incentivo, a cinematografia brasileira pôde ressurgir. Os filmes dessa época, ainda que muito diferentes entre si e incapazes de constituir de fato um movimento, acabaram discutindo as temáticas do sertão, da favela, da pobreza - da compreensão do país, enfim.

Em Terra Estrangeira, entrelaça-se, às histórias de Paco (Fernando Alves Pinto) e de Alex (Fernanda Torres), o desconsolo. Ele já se faz sentir pela fotografia do longa, filmado totalmente em preto e branco, e é gerado pelo Governo Collor, período de padecimento cultural e econômico. A trama, porém, não se desenrola inteiramente no Brasil, intercalando

\footnotetext{
${ }^{6}$ Cf. NAGIB, Lúcia. O Cinema da Retomada: Depoimentos de 90 cineastas dos anos 90. São Paulo: Editora 34, 2002.
} 
os espaços geográficos de São Paulo e Lisboa, num deslocamento que ecoa as modificações experimentadas pelos personagens.

Aí há uma herança de Antonioni, que sempre dizia que os personagens eram transformados, afetados, pelo mundo em que viviam. Acho que todos os movimentos interessantes do cinema são aqueles em que os personagens são transformados pelo entorno. A gente queria que essa fosse a marca de Terra Estrangeira. (SALLES em faixa comentada do DVD, 2005).

Desde o princípio do filme, observa-se, de fato, o zelo do diretor em relação ao "entorno", esse cenário-catalisador de transformações: em plano geral, a primeira cena apresenta um prédio retangular, similar aos que o cercam, com janelas uniformes, indiferenciadas. É noite e as luzes estão apagadas, exceto por um dos apartamentos, de onde se vê um jovem que se movimenta de um lado para o outro, tentando decorar o texto de Fausto, de Goethe. As palavras evocam a coragem, o desbravar do mundo, o enfrentamento da fúria do trovão, a necessidade de se levantar diante das nuvens que se reúnem, apagando a luz da lua. $\mathrm{O}$ enquadramento se alarga, mostrando que o prédio se localiza em frente ao "Minhocão", ou o Elevado Costa e Silva, seu nome oficial, conhecido viaduto da capital paulista. A seu lado, grandes outdoors, vistos pela metade, e o famoso logotipo da Shell, multinacional do petróleo. Há um corte seco, que marca a transição temporal: é dia, e o viaduto, antes vazio, agora é ocupado pelo trânsito intenso e barulhento da megalópole. Enxerga-se, então, a totalidade dos outdoors, que divulgam a marca de cuecas "Mash" e, ironicamente, a lingerie "Hope".

É a deixa para que entre em cena a mãe de Paco, Manoela (Laura Cardoso), que atravessa a rua, carregando pesadas sacolas de supermercado. Na legenda, lê-se "São Paulo, 13 de março de 1990". O passo cansado da velha senhora que, na sequência seguinte, sobe as escadas de paredes descascadas, no prédio em que o elevador não funciona sabe-se lá há quanto tempo, sugere haver bem pouca "esperança" para a pequena família em questão, formada pelo jovem universitário que deseja ser ator e pela humilde costureira, descendente de espanhóis, que sonha em rever sua terra natal, San Sebastian.

O País Basco surge visualmente, no cenário, antes de ser evocado pela palavra: enquanto Manoela descansa, esbaforida, do esforço feito ao subir as escadas, percebe-se, ao fundo, na parede, um pequeno quadro em que se vislumbra a bandeira dessa região, que ostenta uma cultura e um idioma particulares, entre o extremo norte da Espanha e o extremo sudoeste da França. San Sebastian será, para a trama, uma espécie de terra-prometida, terra emoldurada pela utopia difusa da lembrança ou pela beleza adulterada dos cartões postais. 
É por ela que trabalha sem cessar a velha senhora, economizando cada centavo na ânsia de voltar a ver esse lugar onde ela não se sente estrangeira. O filho, porém, tenta trazê-la à realidade, recordando a ela - e, ao mesmo tempo, ao espectador - que a inflação monstruosa no Brasil, no início da década de 1990, inviabilizava a compra de passagens aéreas, ainda que parceladas.

Não são, contudo, os juros estratosféricos nem o realismo do filho que tolhem os sonhos de Manoela, mas a então ministra da Fazenda, Zélia Cardoso de Mello, quando anuncia, em rede nacional, o novo pacote econômico, que confisca as economias depositadas na caderneta de Poupança. Manoela falece, então, pelo desgosto de não poder realizar o sonho pelo qual tanto se empenhara, frente ao televisor ligado, de onde provém, absurdamente, a única luz naquele cenário sombrio. As imagens históricas projetadas pela televisão acentuam o tom realista da obra, possibilitando aos inúmeros brasileiros que passaram pela mesma injustiça a identificação com a personagem.

Paco, jovem de apenas 21 anos, não sabe o que fazer quando, ao voltar para casa, se depara com a morte da mãe. Ele não tem dinheiro sequer para o velório, precisando falsificar a assinatura de Manoela para pagar as despesas mais urgentes. A pobre mulher é enterrada em um cemitério vertical de concreto: os cadáveres ali empilhados reproduzem a arquitetura cinza e homogênea dos prédios das grandes metrópoles, estendendo até a morte o anonimato das classes menos favorecidas.

No enredo, o falecimento materno é também símbolo do desamparo da pátria, que nem de longe é a "mãe-gentil" que o hino nacional reverencia. As cenas que se sucedem ao óbito mostram um filho perdido, desorientado, que fracassa no teste para ator, incapaz de se lembrar do texto que decorara com tanta dedicação. Ele caminha sem rumo, pelas ruas lúgubres de São Paulo, ao lado de mendigos, catadores de lixo, sombras que se arrastam pela noite paulista. É assim que, bêbado e vulnerável, Paco conhece Igor (Luís Mello), um contrabandista que o convence a levar uma encomenda a Portugal, com a promessa de, dessa forma, poder conhecer, no lugar da mãe, a cidade espanhola com que ela tanto sonhara.

A encomenda em questão é um violino, repleto de diamantes. O instrumento faz a transição entre personagens, histórias, espaços. A cena da partida de Paco é também a cena de despedida do Brasil, que só retornará à trama enquanto alusão. A ação passa a se desenrolar em Lisboa, cidade onde o trompetista Miguel (Alexandre Borges) vive com a namorada, Alex. Incapaz de se sustentar apenas com a arte e afeito ao uso de entorpecentes, ele também recorre a atividades ilícitas. Paco deve ir a seu encontro ao chegar a Portugal. Contudo, disposto a deixar o país e viver "na Europa", em suas palavras, Miguel tenta enganar Igor, vendendo, por sua conta, o produto do contrabando precedente. 
Existe, nessa intersecção, um diálogo polifônico com o passado e com o presente. Foram os portugueses que chegaram ao Brasil, em 1500, invadindo o território onde viviam os índios, impondo sua cultura, sua religião, explorando a terra, as minas, levando todo o ouro e o diamante que pudessem encontrar. Essas riquezas acabaram sendo destinadas, em grande parte, aos franceses - sentido que se repete na trama, já que o grande beneficiário de todo o processo de contrabando das joias é um cidadão francês. Ao mesmo tempo, no filme de Walter Salles e Daniela Thomas, não é o português que vai ao Brasil, mas o brasileiro que chega a Portugal, representado por Alex, Miguel, Paco, que buscam uma condição de vida superior à do país de origem. A precariedade brasileira é fruto também de uma ferida história, que é a configuração predatória da colonização portuguesa. Todavia, este país também sofre seu "complexo de vira-lata", muitas vezes nem sendo considerado um país europeu, como revela a fala de Miguel acima transcrita - embora, à época, Portugal já tivesse assinado, pelas mãos do primeiro-ministro Mário Soares, o contrato de adesão à então Comunidade Econômica Europeia (CEE), que viria a se tornar a União Europeia.

Outra conexão intrigante é aquela entre as cidades de São Paulo e Lisboa. São Paulo é o maior centro financeiro e corporativo da América do Sul, possui o $10^{\circ}$ maior PIB do mundo, que representa, isoladamente, mais de 10\% do PIB brasileiro. É também um dos municípios mais populosos do planeta, com mais de 12 milhões de habitantes, distribuídos em uma área de 1521,11 km². Lisboa, por sua vez, tem uma população de meio milhão de pessoas, em uma área de 100,05 km², e é o 67º na lista das 100 cidades com o maior PIB do mundo. Outra diferença marcante - desta vez, entre São Paulo e todo o território português - diz respeito ao fluxo migratório: enquanto Portugal é o segundo país europeu com o maior número de emigrantes (2,3 milhões ou $22 \%$ da população vivem no exterior ${ }^{7}$ ), São Paulo é um dos principais destinos de imigrantes brasileiros e estrangeiros: mais da metade dos imigrantes registrados no Brasil estão ali, englobando, por exemplo, japoneses, italianos, bolivianos e, sobretudo, portugueses ${ }^{8}$.

Em Terra Estrangeira, portanto, os brasileiros fazem o caminho inverso, mas o estigma do colonizado não é deixado para trás. Ele é representado, sobretudo, por Alex, jovem que trabalha como garçonete, sendo explorada pelo patrão português, que a considera preguiçosa e desonesta, "como todos os brasileiros". Em outra cena, ao vender seu passaporte para espanhóis, por um preço bem abaixo do desejado, ela tenta argumentar: “Mas ele é novo", ao que eles respondem, com desprezo: “é brasileiro; não vale nada”.

\footnotetext{
${ }^{7}$ Cf.: https://www.dn.pt/sociedade/interior/portugal-e-o-segundo-pais-da-europa-com-mais-emigrantes-5688739.html (Consulta em: 29 nov. 2017).

${ }^{8}$ Cf.: <https://noticias.uol.com.br/cotidiano/ultimas-noticias/2014/01/23/sao-paulo-tem-mais-da-metade-dosimigrantes-em-situacao-regular-do-pais.htm> (Consulta em 29 nov. 2017).
} 
O título da obra, apresentado logo após os créditos, no início do filme, a propósito, remete a um passaporte sendo carimbado. Nesse caso, porém, é o símbolo da República Federativa do Brasil que recebe o carimbo retangular em que se lê "terra estrangeira", como se o próprio país fosse uma terra estranha a seus filhos, incapaz de oferecer a eles uma vida digna, na qual haveria dinheiro ao menos para se enterrar seus mortos. $\mathrm{O}$ vínculo amoroso que se estabelece entre Alex e Paco é, assim, uma forma de união de dois seres sem pátria, perdidos em um país que não os aceita, mas com medo de retornarem à terra natal que nada garante. Não por acaso, o hotel onde o rapaz se hospeda chama-se sintomaticamente "Viajantes", como se as malas tivessem que estar sempre prontas diante da possibilidade da partida iminente.

Essa estadia ressentida no território do colonizador, essa imbricação histórica, invertida, ganha força também pela presença do núcleo africano na trama. Vindos de Angola, Moçambique, Cabo Verde, esses personagens habitam o mesmo prédio onde se localiza o hotel "Viajantes", vivendo amontoados em um espaço reduzido, e representando a colonização portuguesa no continente africano e seus reflexos. Com seus sotaques diferentes, eles criticam também os brasileiros e, sobretudo, os portugueses, nessa história que reúne, no belo espaço lisboeta, em planos abertos como o mar, tantos lusófonos naufragados.

\section{III}

É justamente para o continente africano que viaja o economista Gabriel Buchmann, no segundo longa-metragem de ficção de Fellipe Gamarano Barbosa, Gabriel e a Montanha (2017). Com João Pedro Zappa no papel do protagonista, o filme mostra a passagem do jovem carioca por quatro países africanos - Quênia, Zâmbia, Tanzânia e Maláui - até o seu falecimento, aos 28 anos, vítima de uma hipotermia no Monte Mulanje, o mais alto pico do Maláui, com mais de 3 mil metros de altitude.

O diretor, que era amigo de Gabriel desde os sete anos de idade, começou a escrever o roteiro logo após receber a notícia de seu desaparecimento, em 2009. Segundo Barbosa, a realização do filme representou uma forma de reencontro não apenas com o jovem como também com o continente africano, onde ele já estivera anos antes (especificamente, na Uganda), atuando como professor de cinema: “Senti também que era uma oportunidade de fazer uma cartografia humana dessa região do mundo tão distante, porém tão próxima de nós. O retrato de uma África humana e hospitaleira, longe dos estereótipos.".

\footnotetext{
${ }^{9}$ Cf.: $<$ http://files-febre.s3.us-east-2.amazonaws.com/s3fspublic/banco_imagens/release/Premiado\%20em\%20Cannes $\% 2 \mathrm{C} \% 20$ filme $\% 20 \%$ E2\%80\%98Gabriel $\% 20 \mathrm{e} \% 20 \mathrm{a} \% 20 \mathrm{Mo}$ ntanha\%E2\%80\%99\%20tem\%20trailer\%20oficial\%20divulgado.pdf?download=1> Consulta em: 28 nov. 2017.
} 
Em 2008, Gabriel partira para uma longa viagem, a fim de se preparar para o doutorado em políticas públicas que realizaria na Universidade da Califórnia. Ele percorre, ao todo, 26 países, na Europa, Ásia, no Oriente Médio e na África, procurando ver de perto a situação de precariedade vivida em muitos desses locais. No último deles, principalmente, o economista se esforça para viajar da maneira mais sustentável possível, hospedando-se na casa dos nativos, compartilhando sua mesa, suas vestimentas, sua cultura, sua língua. Parte do dinheiro economizado era revertida, pelo próprio rapaz, em obras que auxiliavam sobremaneira os anfitriões: ele pagava, por exemplo, o aluguel de vários meses ou a escola de um ano inteiro, com os dólares que não empregava em certos passeios turísticos, restaurantes e hotéis. Isso é o que relata nos e-mails que enviava à namorada, à mãe, à irmã e aos amigos. Essas mensagens, junto às fotos, a um caderno de viagens e ao testemunho dos que com ele estiveram, foram o material utilizado pelo cineasta para reconstituir os últimos meses da vida do carioca.

Outra especificidade importante do filme reside no fato de que, exceto pelo ator que interpreta o protagonista, e Caroline Abras, no papel de sua namorada, Cris, todos os personagens são reais, vividos pelos africanos com os quais Gabriel cruzou pelo caminho. São guias de turismo, mendigos, trabalhadores braçais, motoristas, desconhecidos que, muitas vezes, se tornaram amigos. Em uma das primeiras cenas, um choque temporal: o jovem acorda em uma casa simples, em um cômodo apinhado de crianças, e dá "bom dia" a um menino de cerca de cinco anos, também chamado Gabriel. Mais tarde, o espectador compreende a suposta coincidência: o pai, que conhecera o verdadeiro economista no final da década passada, quisera lhe prestar uma bonita homenagem, dando ao filho o seu nome.

Apesar de toda essa cordialidade e da beleza natural do continente africano, explicitada em planos gerais, nos quais se veem animais, cascatas, uma grande diversidade de vegetações, nem tudo é perfeito nesse cenário. A relação de Gabriel com esse povo hospitaleiro, ao qual ele tenta se misturar, deixa entrever também o abismo que separa o jovem branco de classe média da maioria desses africanos, tão carentes de tantas coisas, externas e internas: comida, remédios, interesse, esperança.

A localização dos homens, das atividades e das coisas no espaço explica-se tanto pelas necessidades "externas", aquelas do modo de produção "puro", quanto pelas necessidades "internas", representadas pela estrutura de todas as procuras e a estrutura das classes, isto é, a formação social propriamente dita (SANTOS, 1977, p.87). 
Entre 2008 e 2009, período em que acontece a viagem, o Brasil vive um momento de prosperidade econômica. Ainda que se vislumbre certa desaceleração no crescimento, em consequência, sobretudo, da "crise do subprime", o contexto brasileiro, de um modo geral, é muito diferente do desalento percebido em Terra estrangeira. Essa circunstância amplia ainda mais o desnível social entre o brasileiro e os africanos, refletindo-se, em algumas ocasiões, em atitudes nas quais se insinua certa arrogância.

A principal delas, é claro, é aquela que encerra prematuramente a viagem do economista. Embora Gabriel já tivesse se aventurado por outras subidas difíceis, como o Kilimanjaro, ponto mais alto do continente africano, ao escalar o Mulanje, ele dispensa o guia que o acompanhava, na expectativa de realizar o percurso mais rapidamente. A mudança de temperatura o pega de surpresa, obrigando-o a ficar mais tempo na montanha, desorientado pela neblina e sem levar consigo o necessário para sua sobrevivência naquelas condições. Desaparecido desde o dia 17 de julho, seu corpo foi encontrado 19 dias depois de sua subida no pico.

O filme de Barbosa, essa mescla de documentário e ficção, apresenta, assim, a história de um jovem idealista, que tenta se infiltrar no continente africano, e acaba sendo, em certa medida, vencido por ele. Favorecido por seu carisma, sua juventude, sua formação acadêmica, sua classe social, pela prosperidade econômica de seu país nesse momento, ele tem tudo para acrescentar o monte Mulanje a sua lista de conquistas. Acaba, contudo, sendo derrotado pela natureza, o clima, o espaço.

\section{Conclusão}

Os três filmes analisados apresentam em comum, além da exploração inteligente do espaço, também o bom uso de seu poder de difusão da cultura brasileira. Essa divulgação é medida, muitas vezes, pelo destaque obtido em festivais, pelas premiações deles resultantes e pelo sucesso junto ao público.

O Som ao redor, por exemplo, em suas sete primeiras semanas de exibição, em 2012, alcançou um público superior a 70 mil espectadores, um número impressionante em se tratando de cinema brasileiro. A obra também foi premiada, na categoria de melhor filme, em diversos festivais, nacionais e internacionais, como o Festival de Gramado, o BFI London Film Festival e o Copenhagen International Film Festival. A lista é ainda mais extensa em relação ao segundo longa-metragem de Kléber Mendonça Filho, Aquarius (2016), ostensivamente aplaudido em Cannes e eleito um dos melhores do ano, por conhecidos mídias, como a revista Cahiers du Cinéma. 
Lançado em um momento em que o cinema brasileiro ainda não tinha a visibilidade de que dispõe atualmente, Terra estrangeira foi mais discretamente condecorado, obtendo prêmios de melhor direção, filme e roteiro, em festivais menos conhecidos. Walter Salles, no entanto, foi responsável por uma série de indicações e troféus: Central do Brasil (Brasil 1998), por exemplo, concorreu ao Oscar nas categorias de melhor filme estrangeiro e melhor atriz, para Fernanda Montenegro. Diários de Motocicleta (2004) concorreu ao Oscar de melhor roteiro adaptado, tendo sido também indicado a cerca de quarenta outros prêmios internacionais, como a Palma de Ouro. Conquistou, dentre outros, o Oscar de melhor canção, por Al otro lado del rio, de Jorge Drexler, e o BAFTA (Reino Unido - 2005) de melhor filme de língua não-inglesa. Salles também assumiu o desafio de levar para as grandes telas um dos mais conhecidos romances norte-americanos, o On the road (1957) de Jack Kerouac. Outros cineastas, como Francis Ford Coppola, Gus Van Sant e Joel Schumacher, em épocas diferentes, haviam arquivado o projeto, diante da dificuldade de adaptação de uma obra tão importante para a Geração Beat e toda a história da literatura. O filme homônimo foi lançado em 2011, em coprodução com a França e o Canadá, sendo nomeado à Palma de Ouro, no Festival de Cannes de 2012.

Quanto a Gabriel e a Montanha, embora ainda se trate de uma produção recente, a obra já foi agraciada com dois prêmios, ambos na Semana da Crítica do Festival de Cannes: de revelação e da Fundação Gan. O filme conquistou o público francês, superando os 50 mil espectadores nas salas de cinema, assim como acontecera com o longa precedente do diretor, Casa grande (2014), que, além dos franceses, atraiu também os brasileiros, sendo eleito, segundo o júri popular no Festival do Rio, o melhor filme desse ano.

Assim, os diretores cujos filmes foram escolhidos para análise neste trabalho ultrapassam as fronteiras da distribuição, do estereótipo, da forma, divulgando um cinema politicamente engajado e artisticamente bem feito. Explorando os espaços em conexão com seus personagens e contextos socais, no interior ou no exterior do país, eles inserem o que pode se considerar um cinema brasileiro de autor na cartografia cultural mundial.

\section{Bibliografia}

BRANDELLERO, Sara. The Brazilian Road Movie: Journeys of (Self) Discovery. Cardiff: University of Wales Press, 2013.

D'AVILA, Roberto. Os Cineastas: conversas com Roberto D'Ávila. Rio de Janeiro: Bom Texto, 2002.

DEBS, Sylvie. Cinéma et littérature au Brésil - Les mythes du Sertão: émergence d'une identité nationale. Paris: L'Harmattan, 2003. 
GONÇALVES, Mariana Mól. Por um cinema humanista: A identidade cinematográfica de Walter Salles, de A grande arte até Abril despedaçado. Orientadora: ANDRADE, Ana Lúcia. Dissertação (Mestrado). Rio de Janeiro: Universidade Federal de Minas Gerais, Escola de Belas Artes, 2008.

MARTIN, Marcel. A linguagem cinematográfica. Trad. Paulo Neves. São Paulo: Brasiliense, 2003.

METZ, Christian. Linguagem e cinema. São Paulo: Editora Perspectiva, 1980.

NAGIB, Lúcia. O Cinema da Retomada: Depoimentos de 90 cineastas dos anos 90. São Paulo: Editora 34, 2002.

RABELLO, Ivone Daré. O Som ao redor: sem futuro, só revanche? In: Novos Estudos (Cebrap), n.101, p.157-173, 2015.

SANTOS, Milton. Sociedade e espaço: a formação social como teoría e como método. In: Boletim Paulista de Geografia, n.54, São Paulo, 1977.

SALLES, Walter; THOMAS, Daniela; BERNSTEIN, Marcos. Terra Estrangeira. (roteiro). Rio de Janeiro: Rocco, 1996. 